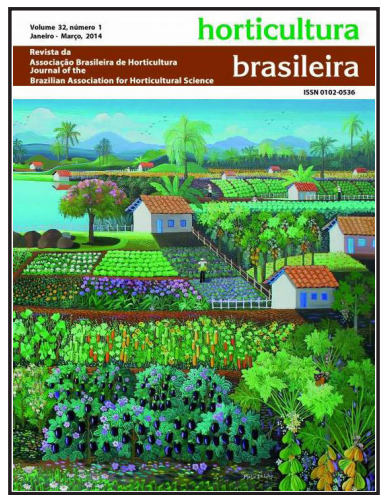

Recorte da obra "Fazenda Pedra Angular", de Malu Delibo. A obra completa e a biografia da autora estão publicadas na terceira capa deste número.

\section{A agricultura familiar no Brasil}

A FAO (Organização das Nações Unidas para a Alimentação e Agricultura) deliberou ser este o "Ano internacional da agricultura familiar" e o governo brasileiro vem organizando diversos eventos destinados a ressaltar sua importância social e econômica. Como a expressão "agricultura familiar" foi fortemente institucionalizada e, assim, utilizada por quase todos, o que significa exatamente? O senso comum parece aceitar que sempre teria sido um conjunto social sem nenhum desafio de definição, sugerindo talvez uma referência aos "pequenos produtores" e apontando para as famílias rurais com menos recursos, inclusive no tocante ao acesso à terra.

Em 2011, publiquei sob o selo da Embrapa, como coautora, um longo artigo intitulado "Agricultura familiar: é preciso mudar para avançar". Nesse estudo, demonstrou-se que, de fato, inexiste um conceito correspondente e, portanto, também não há uma "teoria da agricultura familiar". Pelo contrário, argumentou-se que no Brasil a expressão resultou especialmente da mobilização sindical e da ação de mediadores políticos, animados por visões particulares, por eles desejados, sobre o desenvolvimento das regiões rurais. Desta forma, sem surpresa, pois movida por razões especialmente políticas, a ins- titucionalização da expressão agricultura familiar (em 1995) ignorou ser a agricultura uma atividade que é, primeiramente, econômica.

Excetuado o critério de "administração do estabelecimento" (pela família), os outros preceitos legais, ao contrário, não são econômicos. Segundo o estipulado pela Lei $\mathrm{n}^{\circ} 11.326$ (2006), “(...) considera-se agricultor familiar e empreendedor familiar rural aquele que pratica atividades no meio rural, atendendo, simultaneamente, aos seguintes requisitos: (I) não detenha, a qualquer título, área maior do que quatro módulos fiscais; (II) utilize predominantemente mão-de-obra da própria família (...); (III) tenha renda familiar predominantemente originada de atividades econômicas vinculadas ao próprio estabelecimento ou empreendimento." Daí a pergunta: por que esses critérios não se prenderam estritamente à natureza econômica das atividades agropecuárias?

$\mathrm{O}$ primeiro requisito diz respeito ao tamanho do estabelecimento. Em todo o país, são limites que podem comportar atividades produtivas muito distintas, englobando desde subconjuntos totalmente integrados a mercados, como certos tipos de produção de hortaliças, a outros casos de famílias com rendas muito baixas e vivendo em relativa pobreza, ainda que detentoras de áreas maiores.

O segundo critério sugere que se utilize "predominantemente mão-de-obra da própria família”. Mas, por que esses produtores não poderiam contratar trabalhadores? Se existem inúmeras empresas que são familiares, em outros ramos produtivos que não a agricultura, mas contratam muitos trabalhadores assalariados, por que somente os pequenos produtores rurais não poderiam fazê-lo, à medida que suas atividades cresçam e, assim, mais trabalhadores são necessários ao processo produtivo? De fato, a justificativa para esta exigência, na origem da lei, é meramente política. A razão é uma teoria de exploração social que é parte de algumas tradições teóricas das Ciências Sociais, normalmente perspectivas anticapitalistas. Sob tal orientação, são teorias que demonizam "os patrões" do mundo rural e, por via de consequência, defendiam (e defendem) que o mundo rural deve ser ocupado somente por propriedades familiares, nas quais os membros da família sejam, também, os próprios trabalhadores, não existindo assim a exploração do trabalho assalariado.

Confrontada, contudo, com as realidades das regiões rurais, onde a contratação de trabalhadores externos ocorre amiúde, a saída encontrada foi incorporar o "predominantemente" sugerido na Lei, abrindo uma janela para a contratação "esporádica" de um pequeno número de assalariados rurais por parte dos pequenos produtores. Mas, um critério que nem remotamente foi motivado por qualquer justificativa econômica.

Finalmente, o terceiro requisito estipulado é ainda mais excêntrico ao prever que a adjetivação "familiar", na prática, estabeleça um teto para o nível de ganho das famílias rurais, pois a “(...) a renda familiar [precisa ser] predominantemente originada de atividades econômicas vinculadas ao próprio estabelecimento". A justificativa para este critério não se sustenta sob nenhum argumento econômico. As experiências de sociedades onde a agricultura mais se desenvolveu indicam, pelo contrário, que as famílias rurais ampliaram as suas chances de prosperidade exatamente quando alguns de seus membros diversificaram suas atividades, seja o trabalho rural não agrícola ou aquele fora das regiões rurais, embora continuassem residindo com a família no estabelecimento. Em praticamente todas as situações, o trabalho fora da propriedade tem sido uma forma de complementação de renda essencial à manutenção da propriedade rural. Como explicar este preceito tão estranho no caso brasileiro?

A hipótese apresentada no artigo citado para explicar este esdrúxulo terceiro critério é que sua inserção deve-se ao imaginário religioso imperante em áreas rurais. Em especial, entre os dirigentes sindicais e operadores políticos que estiveram presentes na formulação da ideia sobre agricultura familiar na primeira metade da década de 1990. Suas visões de mundo sempre mantiveram um ideal de sociedade rural que continha tonalidades idílicas de preservação de comunidades integradas por pequenos produtores dedicados à produção do autoconsumo e "protegidos" da ação dos mercados.

É preciso portanto, mudar a lei brasileira da "agricultura familiar". É preciso reconhecer com urgência que a agricultura é uma atividade econômica e, assim, estabelecer critérios correspondentes para delimitar este conjunto social, abandonando os requisitos que, acima discutidos, não se aplicam às realidades rurais. Assim, a expressão agricultura familiar passará a ter um significado concreto e não, como ocorre no Brasil, especialmente ideológico.

(Maria Thereza Macedo Pedroso, pesquisadora da Embrapa Hortaliças; maria. pedroso@embrapa.br)

As idéias aqui expressas e as informações apresentadas são de responsabilidade do autor. 